\title{
Male degus, Octodon degus, modify their dustbathing behavior in response to social familiarity of previous dustbathing marks
}

\author{
Machos de Octodon degus modifican su conducta de baños de tierra en respuesta a la \\ familiaridad social de marcas previas
}

\author{
LUIS A. EBENSPERGER ${ }^{1} \&$ ANDREA CAIOZZI
}

Centro de Estudios Avanzados en Ecología \& Biodiversidad, Departamento de Ecología, Facultad de Ciencias Biológicas, P. Universidad Católica de Chile,

Casilla 114-D, Santiago, Chile; e-mail'1: lebenspe@genes.bio.puc.cl

\begin{abstract}
A previous experiment suggested that male degus, Octodon degus, use dustbathing during intrasexual communication. Herein, we assessed whether dustbathing by male and female degus is influenced by the social familiarity of previous marks. During 15-min tests, we contrasted the behavior of degus individually exposed during to an arena containing loose, previously dustbathed sand by a same-sex and socially familiar individual with that of degus exposed to an arena with soil previously dustbathed by a same-sex but socially unfamiliar conspecific. We measured the number of dustbathing events per min, the latency to first dustbathing event, and the location of dustbathing events by depositor and responder individuals. Both male and female degus dustbathe at a higher rate when subjected to soil previously used by a familiar conspecific than when exposed to a substratum previously dustbathed by an unfamiliar degu. The latency to first dustbathing event by responder male or female degus was unaffected by the social familiarity of previous marks left by depositors. Similarly, the place chosen by male and female responders to conduct their dustbathing behavior was unrelated to the micro-location of previous marks left by a familiar or an unfamiliar depositor degu. We conclude that degus are capable of discriminating socially familiar from unfamiliar scents of conspecifics and deposited in the substratum during dustbathing. We discuss the implications of such ability in the context of degu social behavior.
\end{abstract}

Key words: social familiarity, sandbathing, scent marking, social communication.

\section{RESUMEN}

Un experimento previo reveló que machos del roedor Octodon degus modifican su conducta de baños de tierra en respuesta a marcas previas de otros individuos del mismo sexo. En este estudio evaluamos si los baños de tierra de machos y hembras de este roedor son o no afectados por la familiaridad social de marcas previas. Para ello, comparamos el comportamiento de degus expuestos individualmente durante experimentos de $15 \mathrm{~min}$ a una arena experimental marcada previamente por individuos (del mismo sexo) socialmente conocidos o desconocidos. En estas condiciones, cuantificamos la latencia (tiempo transcurrido hasta el primer baño de tierra), la tasa (número de eventos por min) y la ubicación micro-espacial de los baños de tierra efectuados por cada degu respondedor. Machos y hembras efectuaron un mayor número de baños de tierra ante la presencia de marcas de individuos socialmente conocidos comparado con marcas de individuos desconocidos. En cambio, la latencia y la posición de los baños de tierra efectuados por degus respondedores no fueron afectados por el sexo de los respondedores ni por la familiaridad social de las marcas previas. Concluimos que degus macho y hembra discriminan entre marcas odoríferas depositadas durante baños de tierra previos por parte de individuos socialmente conocidos y desconocidos. Discutimos las implicancias de estos resultados en términos del comportamiento social de este roedor.

Palabras clave: baños de tierra, comportamiento social, comunicación social, familiaridad social.

\section{INTRODUCTION}

Communication occurs when signals given by one animal influence the behavior of another (Krebs \& Davies 1993, Johnstone 1997). The nature of signals range widely, including visual (e.g., brightly colored body parts), auditory (e.g., calls, drumming), olfactory (e.g., pheromones), and tactile (e.g., grooming) signals (Feldhamer et al. 1999). Such signals may serve to attract a mate, to deter a competitor, or to warn conspecifics of an approaching predator (Krebs \& Davies 1993, Johnstone 1997).

Most mammals produce chemical odors to signal sex, breeding status, rank of dominance, or territory ownership. Behaviors associated with the deposition of these chemical signals often are highly specialized (Vaughan 1986, Feldhamer et al. 1999). Dustbathing (or sandbathing) could be one such specialized behavior. During dustbathing 
small mammals typically dig briefly into the ground with their fore claws and rubs their sides and ventrum in the dust (Eisenberg 1963, Eisenberg \& Kleiman 1972, Randall 1993).

Among rodents, dustbathing has been documented in several species of kangaroo rats (Heteromyidae), jerboas (Dipodidae), gerbils (Muridae), and squirrels (Sciuridae) (Steiner 1974, Wistrand 1974, Daly \& Daly 1975, Betts 1976, Owings et al. 1977, Randall 1994). Dustbathing regulates the level of oil secretions in the pelage, which in turn influences the thermoregulatory efficiency of mammals such as rodents (Borchelt et al. 1976, Griswold et al. 1977, Randall 1981a). However, dustbathing also seems related to social communication (Eisenberg 1963, 1981) where the source of odor signals include sebaceous glands associated with the hair and specialized scent glands (Eisenberg 1963, Randall 1987, 1991, 1993, 1994). Dustbathing has been implicated in social communication of solitary-living heteromyids, including Merriam's kangaroo rats (Dipodomys merriami) and, to a lesser extent, Great Basin kangaroo rats (D. microps) where individuals are generally attracted to dustbathing marks left by either sex conspecifics (Randall 1981b). Moreover, the possibility that these rats use dustbathing to signal burrow/territory ownership has been suggested (Randall 1987).

Dustbathing also has been linked to social communication of group-living rodents such as the Mongolian gerbil, Meriones unguiculatus (Ågren et al. 1989), the yellow-toothed cavies, Galea spixii (Lacher 1981) and Galea musteloides (Rood 1972), plains vizcachas, Lagostomus maximus (Branch 1993), and dwarf maras Dolichotis salinicola (Wilson \& Kleiman 1974). Moreover, dustbathing also might be used by social Mongolian gerbils to mark their communal territories (Ågren et al. 1989).

Besides territorial marking, dustbathing loci and other substrate-born scents have been hypothesized to signal group-membership by social species to maintain familiarity among group members, which would increase group cohesion (Steiner 1974, Hare 1994, Brady \& Armitage 1999). For instance, Columbian ground squirrels (Spermophilus columbianus) recognize group members through a process of indirect familiarization that relies upon substrate-born chemical cues (Hare 1994).

Even if dustbathing functions to promote groupcohesion or to signal burrow/territory ownership, individuals are expected to discriminate social familiarity of deposited scents. Among less social species, bannertail (D. spectabilis), Merriam's, and giant (D. ingens) kangaroo rats discriminate familiar from unfamiliar conspecifics on the basis of body oils and dorsal gland secretions left at dustbathing loci (Randall 1987, 1991, Murdock \& Randall 2001). Similarly, male red squirrels pay more attention to odors from unfamiliar than to odors from familiar conspecifics (Vaché et al. 2001). The objective of this study was to test if males and females of the groupliving rodent, Octodon degus, are capable of discriminating scents deposited in the substratum through dustbathing by same-sex but socially familiar and non-familiar conspecifics. In particular, we mimicked a situation where an individual intruder confronts socially familiar (i.e., from same group) and socially unfamiliar (i.e., from different group) marks while outside its regular home range, and assessed if such individuals modify their dustbathing behavior accordingly.

Degus are diurnal, group-living rodents of semiarid scrub areas of central Chile (Woods \& Boraker 1975, Redford \& Eisenberg 1992), and groups are suspected to defend a communal territory (Fulk 1976). Scent marking with urine by degus is influenced by the presence of scent marks of same-sex conspecifics (Kleiman 1975). Among the New World octodontid rodents, degus do dustbathe (Fulk 1976), and several lines of evidence suggest that degus use substrate-born chemical cues in a context of social communication. Captive degus dustbathe at sites that are frequently urine marked (Wilson \& Kleiman 1974), and agonistic encounters among free-ranging animals may include dustbathing by one or both contenders (Fulk 1976, L.A. Ebensperger personal observations, although see Davis 1975). Finally, male, but not female, degus dustbathe less upon the detection of previous marks deposited by socially unfamiliar same-sex conspecifics (Ebensperger 2000), and dustbathing by free-ranging degus tends to increase during breeding time (L.A. Ebensperger unpublished results).

\section{MATERIAL AND METHODS}

Experimental ("responder") and familiar "depositor" subjects were laboratory reared degus born to pregnant females caught during 1999 at Lampa (33 $\left.17^{\circ} \mathrm{S}, 70^{\circ} 53^{\prime} \mathrm{W}\right), 30 \mathrm{~km}$ northwest of Santiago. Upon weaning, degus were kept in same sex-sibling or same sex-non sibling pairs inside 450 by 230 by $210 \mathrm{~mm}$ clear polycarbonate rat cages with a bedding of hardwood chips. Food (commercial rabbit pellet) and water were provided ad libitum. Animals were kept in a ventilated room in which ambient temperature 
was maintained at $21 \pm 1{ }^{\circ} \mathrm{C}(\overline{\mathrm{x}} \pm \mathrm{SD})$, with a 12 h light: $12 \mathrm{~h}$ dark cycle (with lights on at 07:00 h), which roughly matches the natural daylength during most of degus' breeding time. Responder degus were $54.7 \pm 1.9$ weeks old (i.e., fully adult), sexually inexperienced, but reproductively competent when observations began. Male responders were heavier $(268.7 \pm 35.1 \mathrm{~g}, \mathrm{n}=11)$ than female responders $(226.9 \pm 31.6 \mathrm{~g}, \mathrm{n}=17)$ (Student t-test, $\mathrm{t}_{27}=3.32, \mathrm{P}=0.003$ ).

Adult degus used as unfamiliar depositors (two males and five females) were live-trapped at Fundo Rinconada de Maipú, (33'29” S, 70'54” W), $30 \mathrm{~km}$ west of Santiago, during the austral autumn of 2000 (i.e., when most mating activity takes place). Although the precise age of depositors was unknown, all were adult sized when caught. Unfamiliar depositor degus were caged individually and maintained under the same laboratory conditions described above, but in a different room from that housing the experimental degus. The origin and housing conditions during captivity of depositors ensured they were totally unfamiliar to responder degus. Kinship among depositor degus was unknown. Unfamiliar depositors were kept an average of $5(\mathrm{SD}=1.7)$ weeks in captivity before being used in the experiments. Despite differences in the history of captivity between familiar and unfamiliar depositors, they did not differ in their scent marking behavior. Thus, the number of dustbathing events per min (see below) was similar among familiar and unfamiliar (two-way ANOVA, familiarity $-\mathrm{F}_{1,17}=0.81, \mathrm{P}=0.377$ ) and between male and female $\left(\mathrm{sex}-\mathrm{F}_{1,17}=2.01, \mathrm{P}=\right.$ 0.168 ) depositors.

We used a circular-shaped arena made of opaque aluminum panels, with a diameter of $1.98 \mathrm{~m}$ and height of $1.5 \mathrm{~m}$. The arena was placed into a room illuminated with eight $40 \mathrm{~W}$ "fluorescent" bulbs. Before each experiment, the bottom of the arena was covered with a homogeneous 5-10 mm layer of loose and dry sand, commercially available. Temperature of experimental room was $21 \pm 3{ }^{\circ} \mathrm{C}$ $(\overline{\mathrm{x}} \pm \mathrm{SD})$.

Responder degus were randomly assigned to one of two groups such that sex and kinship were balanced. Degus in the first group (unfamiliar responders) were observed while inside the arena when it contained sand previously dustbathed by a same-sex and socially unfamiliar depositor degus. A second group of degus (familiar responders) was observed while inside the arena when it contained soil previously dustbathed by a same-sex but socially familiar depositor degu. Familiar depositors were cage mates of responders.
We began each test by placing a single depositor degu into the arena containing clean soil. Depositor degus were left undisturbed for $30 \mathrm{~min}$ after which they were removed; we carefully removed any sand spot with urine or feces left by the depositor and replaced the removed sand with a similar amount of clean, unused sand. We immediately introduced a responder degu into the arena and left it undisturbed for $15 \mathrm{~min}$. We chose this trial length for two reasons. First, a relatively short time of exposure may better simulate natural conditions in which an animal finds a dustbathing site but it is not confined to remain close to it. Secondly, the 15-min trial length will make our results comparable with previous studies.

Upon completing each experiment, animals were returned to their original cage, and all sand in the arena was discarded. Experiments were carried out between 13:00 and 17:00 h, from August to November 2000. While all responding degus were used only once, depositors were used 2-6 times each, at a frequency of once every two weeks.

Behavior of all animals was videotaped with a Sony video camera recorder (model CCD-TR416), mounted on a tripod at a height of $2.5 \mathrm{~m}$ above floor level, and connected to a TV monitor. We then used the videotapes to record the latency (time to first dustbathing, in sec), the rate (number of events per min), and the location of dustbathing events throughout the observation period. To assess the influence of location of dustbathing events by depositors on the location of dustbathing by responder degus, we mapped the location of dustbathing events by depositor and responder degus on a paper grid representing the whole arena. To do so, the arena was divided into five quadrants; one circularly shaped on the center and four similarly cone-shaped quadrants on the periphery. We chose the quadrants such that the total area of each was the same. We overlapped this grid to our TV screen monitor to record the number of dustbathing events directed at previously marked quadrants, and the percentage of experimental time spent by responders in the most previously marked quadrant.

We carried out statistical analyses with Statistica 5.1 for Windows (StatSoft Inc., Tulsa, Oklahoma). Upon checking homogeneity of variances in each case, we examined the behavior of male and female responders with the use of parametric statistics. We followed Zar (1996), who recommends the transformation of percentages to arcsin of squared root values before using parametric tests. Since latency to first dustbathing event might be correlated with the rate of subsequent dustbathing, we used multivariate analysis of variance 
(MANOVA). Throughout the text data are presented as $\overline{\mathrm{x}} \pm \mathrm{SD}$.

\section{RESULTS}

Eleven male and 17 female degus served as responder subjects. Dustbathing typically involved a degu rubbing its left and/or right sides against the substratum. Left and right sides were rubbed in an alternating fashion (for further behavioral details see Ebensperger 2000).

As expected, male or female responders who took longer to first dustbathing event were also more likely to dustbathe less (Pearson $\mathrm{r}=-0.50$, $\left.\mathrm{F}_{1,21}=7.05, \mathrm{P}=0.015\right)$. Our MANOVA revealed that familiarity with previous marks significantly influenced the dustbathing behavior of male and female responders when both latency to first dustbathing event and the rate of dustbathing were considered jointly ( $R$ ao's $\mathrm{R}_{2,18}=3.84, \mathrm{P}=$ $0.041)$. In contrast, neither the sex of responders (Rao's $\mathrm{R}_{2,18}=0.17, \mathrm{P}=0.846$ ) nor its interaction with the social familiarity of previous marks (Rao's $\mathrm{R}_{2,18}=0.04, \mathrm{P}=0.962$ ) influenced these two aspects of dustbathing behavior. Regarding the influence of these factors in each dependent variable, the rate dustbathing $\left(\mathrm{F}_{1,19}=5.18, \mathrm{P}=\right.$ $0.035)$, but not the latency $\left(\mathrm{F}_{1,19}=0.01, \mathrm{P}=0.919\right.$, Table 1), was influenced by familiarity with previous marks. Thus, male and female responders dustbathed 2.7 and 3.3. times more when subjected to sand previously dustbathed by a familiar samesex conspecific, respectively (Fig. 1).

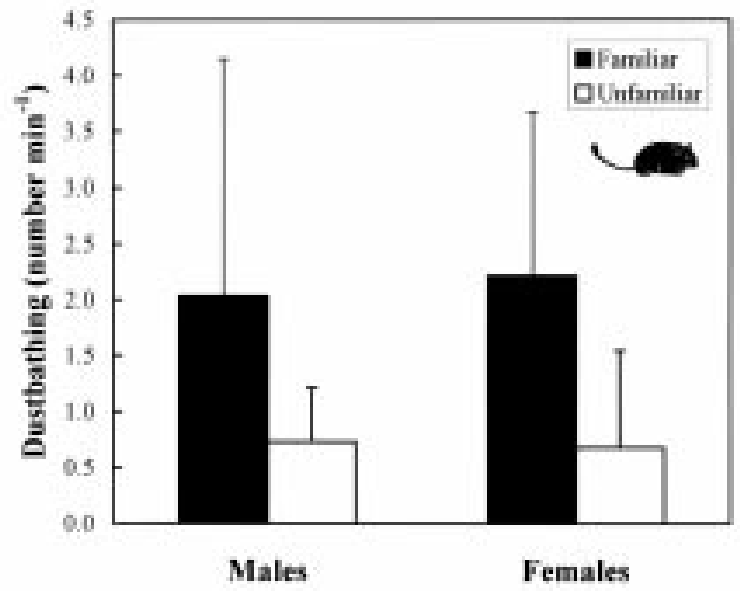

Fig. 1: Number of dustbathing events per min by individual male and female Octodon degus during 15-min trials when exposed to an arena with sand previously dustbathed by a same-sex socially familiar or socially unfamiliar conspecific. Bars are $\overline{\mathrm{x}} \pm \mathrm{SD}$.

Número de baños de tierra por min por parte de degus macho y hembra durante períodos de 15 min en una arena experimental con suelo previamente marcado por degus (del mismo sexo) socialmente conocidos o desconocidos. Las barras corresponden a $\overline{\mathrm{x}} \pm \mathrm{DE}$.

The micro-spatial location of previous marks left by same-sex depositors did not influence the dustbathing behavior of male and female responders. The percentage of dustbathing events that male and female responders directed at the most previously marked quadrant did not vary

Number of dustbathing events directed and time spent by male and female responder degus at the quadrant most previously dustbathed by a (same sex) socially familiar and a by a socially unfamiliar depositor degu. Values are $\bar{x} \pm$ SD of untransformed percentages

Número de baños de tierra efectuados y tiempo destinado por degus machos y hembras respondedores al cuadrante más marcado previamente por un degu (del mismo sexo) socialmente conocido o desconocido. Los valores corresponden a $\overline{\mathrm{X}} \pm \mathrm{DE}$ de porcentajes no transformados

\begin{tabular}{|c|c|c|c|}
\hline Variable & Sex & Familiar & Unfamiliar \\
\hline \multirow[t]{2}{*}{ Latency (sec) } & Female & $\begin{array}{c}91 \pm 145 \\
(\mathrm{n}=8)\end{array}$ & $\begin{array}{c}100 \pm 96 \\
(n=5)\end{array}$ \\
\hline & Male & $\begin{array}{c}120 \pm 160 \\
(\mathrm{n}=5)\end{array}$ & $\begin{array}{c}100 \pm 55 \\
(\mathrm{n}=5)\end{array}$ \\
\hline Dustbathing (\%) & Female & $\begin{array}{c}34 \pm 33 \\
(\mathrm{n}=9) \\
29 \pm 21 \\
(\mathrm{n}=5)\end{array}$ & $\begin{array}{c}42 \pm 36 \\
(\mathrm{n}=8) \\
17 \pm 19 \\
(\mathrm{n}=6)\end{array}$ \\
\hline \multirow[t]{2}{*}{ Time $(\%)$} & Female & $\begin{array}{c}25 \pm 16 \\
(\mathrm{n}=9)\end{array}$ & $\begin{array}{c}26 \pm 24 \\
(\mathrm{n}=8)\end{array}$ \\
\hline & Male & $\begin{array}{c}34 \pm 29 \\
(\mathrm{n}=5)\end{array}$ & $\begin{array}{c}23 \pm 13 \\
(\mathrm{n}=6)\end{array}$ \\
\hline
\end{tabular}


with the social familiarity of previous marks (twoway ANOVA, familiarity- $\mathrm{F}_{1,24}=0.79, \mathrm{P}=0.384$ ) or with the sex of responders $\left(\operatorname{sex}-\mathrm{F}_{1,24}=0.21, \mathrm{P}\right.$ $=0.650$, Table 1). Similarly, the time spent by responder degus within the most previously dustbathed quadrant did not vary with the familiarity of previous marks (familiarity- $\mathrm{F}_{1,24}=$ $0.31, \mathrm{P}=0.581$ ) or with the sex of responders $\left(\mathrm{sex}-\mathrm{F}_{1,24}=0.21, \mathrm{P}=0.650\right.$, Table 1$)$.

\section{DISCUSSION}

During a previous study, male but not female degus decreased their rate of dustbathing from $4.0 \pm 2.3$ events $\min ^{-1}$ to $1.1 \pm 1.2$ events $\mathrm{min}^{-1}$ upon the presence of dustbathing marks left by other, same-sex unfamiliar males as compared with clean, unused soil, respectively (Ebensperger 2000). During this study, we observed both male and female degus to increase their dustbathing activity when exposed to soil previously scent marked by a same-sex familiar (i.e., same group) conspecific. Taken together, these findings imply that degus react to the presence and are capable of discerning the familiarity of scents deposited in the substratum during dustbathing.

What is the functional meaning of such ability? Common degus live in relatively small social units, including two to five females and one to two males, which share a feeding range and an underground system of burrows (Woods \& Boraker 1975, Fulk 1976, Yáñez 1976, Mann 1978); groups are suspected to defend a communal territory (Fulk 1976). Given that degus typically dustbathe at the entrance of their burrows (Fulk 1976, L.A. Ebensperger unpublished results), scents deposited at these dustbathing loci may communicate burrow occupancy and function in territorial defense by means of causing nongroup members (potential intruders) to withdraw. Such function would parallel the role of dustbathing behavior of bannertail kangaroo rats (Randall 1987), Mongolian gerbils (Ågren et al. 1989), and the cheek-rubbing activity of yellow-bellied marmots, Marmota flaviventris (Brady \& Armitage 1999). The tendency of degus to dustbathe more upon the presence of previous marks from socially familiar (same group) individuals would function to strengthen the intensity of the signal. Weather scents alone (i.e., the scent-fence hypothesis) or the matching between scents and signalers (territory owners; i.e., the scent-matching hypothesis) would keep out intruders need to be explored (Heth \& Todrank 1997, Rosell et al. 1998, 2000, Sun \& MüllerSchwarze 1998).
Substrate-born scents, including dustbathing loci, also may be used by social species to signal group-membership and maintain familiarity among group members, which would increase group cohesion (Steiner 1974, Hare 1994, Brady \& Armitage 1999). For instance, Columbian ground squirrels (Spermophilus columbianus) recognize group members through a process of indirect familiarization that relies upon substrateborn chemical cues (Hare 1994), and individual yellow-bellied marmots has been suggested to use cheek-marking to communicate their presence to other group members (Brady \& Armitage 1999). The observation that degus are particularly attracted to dustbathe in the presence of previous scents by socially familiar (i.e., same group) animals is also consistent with this interpretation.

Results from this study and those of Ebensperger (2000) have revealed that both male and female degus dustbathe more in the presence of previous marks left by same-sex, familiar (i.e., from same group) individuals, but that only males increase their dustbathing at clean, unmarked soil. Such sexual differences might, to some extent, reflect different functions of male and female dustbathing. Thus, male dustbathing may be more related to territorial defense, which would be consistent with the observations that the willingness of males to tolerate the presence of other males decreases during the breeding season (Solis \& Rosenmann 1990), and that dustbathing (by males?) increases during breeding time (L.A. Ebensperger unpublished results). In contrast, female dustbathing might function to maintain familiarity and cohesion among group members, which would be consistent with the observation that degu groups are strongly female biased.

Dustbathing might be coupled to other sources of chemical scents. Thus, scent marking with urine and other behavioral responses of degus are influenced by the presence of scent marks of same-sex conspecifics (Kleiman 1975, Fischer \& Meunier 1985). More interestingly, captive degus dustbathe at sites that are frequently urine marked (Wilson \& Kleiman 1974), and dustbathing loci near burrows of free-ranging degus are also impregnated with feces and urine (Fulk 1976, Yáñez 1976, L.A. Ebensperger unpublished results).

Our study suggested that the micro-spatial location of previous marks left by same-sex conspecifics does not affect where male and female degus direct their dustabathing behavior. The size of our grid patches used to map the location of dustbathing events $\left(0.63 \mathrm{~m}^{2}\right)$ may have been too large to detect any avoidance of degus for certain spots during dustbathing. However, the use of a 
smaller grid size $\left(0.25 \mathrm{~m}^{2}\right)$ during a previous study provided similar results (Ebensperger 2000). Alternatively, our experimental conditions may have failed to provide degus with salient clues that these rodents would use to direct their dustbathing activity. Such clues may include the burrow openings and their associated piles of feces and loose dirt (deposited during digging activity). Regarding the no influence of our experimental conditions on the time to first dustbathing event (latency), we pose that latency may more accurately reflect propensity of degus to dustbathe under experimental conditions where degus are more freely to move and leave.

Future studies need to determine the nature and origin of degu scents deposited during dustbathing. Secondly, we might gain more on the functional meaning of dustbathing if experimental tests of hypotheses include both the behavior of territory owners (or group members) and that of intruders (nongroup members). In addition to further experimental studies, a comparative approach is warranted. Dustbathing is less developed in some tropical heteromyids (Eisenberg 1963), rare in wild cavies, Cavia aperea (Rood 1972), and absent in the rock cavy, Kerodon rupestris (Lacher 1981). Such variation in the occurrence and extent of dustbathing across species could be used to conduct comparative studies and test the roles of social communication and pelage maintenance on the evolutionary origin of this behavior.

\section{ACKNOWLEDGMENTS}

We are greatly indebted to Rosanna Ginocchio and Juan Correa who provided the space needed to carry out the experiments. We thank Universidad de Chile and particularly, Daniel García (Field Station Administrator), for allowing us the access to their field station. Comments by James Hare and Rodrigo Vásquez greatly improved previous versions of the manuscript. This study was partially funded by a post-doctorate FONDECYT grant 3970028 to the first author.

\section{LITERATURE CITED}

ÅGREN G, Q ZHOU \& W ZHONG (1989) Ecology and social behaviour of Mongolian gerbils, Meriones unguiculatus, at Xilinhot, inner Mongolia, China. Animal Behaviour 37: 11-27.

BETTS BJ (1976) Behaviour in a population of Columbian ground squirrels, Spermophilus columbianus columbianus. Animal Behaviour 24: 652-680.
BRADY KM \& KB ARMITAGE (1999) Scent-marking in the yellow-bellied marmot (Marmota flaviventris). Ethology Ecology \& Evolution 11: 35-47.

BORCHELT PL, JG GRISWOLD \& RS BRANCHEK (1976) An analysis of sandbathing and grooming in the kangaroo rat (Dipodomys merriami). Animal Behaviour 24: 347-353.

BRANCH LC (1993) Social organization and mating system of the plains viscacha (Lagostomus maximus). Journal of Zoology (London) 229: 473-491.

DALY M \& S DALY (1975) Socio-ecology of Saharan gerbils, especially Meriones libycus. Mammalia 39: 289-311.

DAVIS TM (1975) Effects of familiarity on agonistic encounter behavior in male degus (Octodon degus). Behavioral Biology 14: 511-517.

EBENSPERGER LA (2000) Dustbathing and intra-sexual communication of social degus, Octodon degus (Rodentia: Octodontidae). Revista Chilena de Historia Natural 73: 359-365.

EISENBERG JF (1963) A comparative study of sandbathing behavior in heteromyid rodents. Behaviour 22: 16-23.

EISENBERG JF (1981) The mammalian radiations: an analysis of trends in evolution, adaptation, and behavior. University of Chicago Press, Chicago, Illinois. $610 \mathrm{pp}$.

EISENBERG, JF \& DG KLEIMAN (1972) Olfactory communication in mammals. Annual Review of Ecology and Systematics 3: 1-32.

FELDHAMER GA, LC DRICKAMER, SH VESSEY \& JF MERRITT (1999) Mammalogy: adaptation, diversity, and ecology. McGraw-Hill, Boston, Massachusetts. $563 \mathrm{pp}$.

FISCHER RB \& GF MEUNIER (1985) Responses to conspecific's urine by the degu (Octodon degus). Physiology \& Behavior 34: 999-1001.

FULK GW (1976) Notes on the activity, reproduction, and social behavior of Octodon degus. Journal of Mammalogy 57: 495-505.

GRISWOLD JG, PL BORCHELT, RS BRANCHEK \& JA BENSKO (1977) Condition of the pelage regulates sandbathing and grooming behaviour in the kangaroo rat (Dipodomys merriami). Animal Behaviour 25: 602-608.

HARE JF (1994) Group member discrimination by Columbian ground squirrels via familiarity with substrate-borne chemical cues. Animal Behaviour 47: 803-813.

HETH G \& J TODRANK (1997) Patterns of urination of a blind subterranean rodent, Spalax ehrenbergi. Ethology 103: 138-148.

JOHNSTONE RA (1997) The evolution of animal signals. In: Krebs JR \& NB Davies (eds) Behavioural ecology: an evolutionary approach: 155-178. Blackwell Science, Oxford, United Kingdom.

KLEIMAN DG (1975) The effects of exposure to conspecific urine on urine-marking in male and female degus (Octodon degus). Behavioral Biology 14: 519526.

KREBS JR \& NB DAVIES (1993) An introduction to behavioural ecology. Third edition. Blackwell Scientific Publications, Cambridge, United Kingdom. 420 pp. 
LACHER TE (1981) The comparative social behavior of Kerodon rupestris and Galea spixii and the evolution of behavior in the Caviidae. Bulletin of Carnegie Museum of Natural History 17: 1-71.

MANN G (1978) Los pequeños mamíferos de Chile: marsupiales, quirópteros, edentados y roedores. Gallana Zoología (Chile) 40: 1-342.

MURDOCK HG \& JA RANDALL (2001) Olfactory communication and neighbor recognition in giant kangaroo rats. Ethology 107: 149-160.

OWINGS DH, BORCHELT M \& R VIRGINIA (1977) The behaviour of California ground squirrels. Animal Behaviour 25: 221-230.

RANDALL JA (1981a) Comparison of sandbathing and grooming in two species of kangaroo rat. Animal Behaviour 29: 1213-1219.

RANDALL JA (1981b) Olfactory communication at sandbathing loci by sympatric species of kangaroo rats. Journal of Mammalogy 62: 12-19.

RANDALL JA (1987) Sandbathing as a territorial scentmark in the bannertail kangaroo rat, Dipodomys spectabilis. Animal Behaviour 35: 426-434.

RANDALL JA (1991) Sandbathing to establish familiarity in the Merriam's kangaroo rat, Dipodomys merriami. Animal Behaviour 41: 267-275.

RANDALL JA (1993) Behavioural adaptations of desert rodents (Heteromyidae). Animal Behaviour 45: 263 287.

RANDALL JA (1994) Convergences and divergences in communication and social organisation of desert rodents. Australian Journal of Zoology 42: 405-433.

REDFORD KH \& JF EISENBERG (1992) Mammals of the Neotropics: the southern cone. University of Chicago Press, Chicago, Illinois. 430 pp.

ROOD JP (1972) Ecological and behavioural comparisons of three genera of Argentine cavies. Animal Behaviour Monographs 5: 1-83.

ROSELL F, F BERGAN \& H PARKER (1998) Scentmarking in the Eurasian beaver (Castor fiber) as a means of territory defense. Journal of Chemical Ecology 24: 207-219.

Associate Editor: F. Bozinovic

Received October 11, 2001; accepted November 16, 2001
ROSELL F, G JOHANSEN \& H PARKER (2000) Eurasian beavers (Castor fiber) behavioral response to simulated territorial intruders. Canadian Journal of Zoology 78: 931-935.

SOLIS R \& M ROSENMANN (1990) Seasonal changes in intermale interactions and metabolism of Octodon degus. In: Gutiérrez $\mathrm{O}$ (ed) Comparative psychobiology of aggression: 51-64. Professors World Peace Academy, Santiago, Chile.

STEINER AL (1974) Body-rubbing, marking, and other scent-related behavior in some ground squirrels (Sciuridae), a descriptive study. Canadian Journal of Zoology 52: 889-906.

SUN L \& D MÜLLER-SCHWARZE (1998) Beaver response to recurrent alien scents: scent fence or scent match? Animal Behaviour 55: 1529-1536.

VACHÉ M, J FERRON \& P GOUAT (2001) The ability of red squirrels (Tamiasciurus hudsonicus) to discriminate conspecific olfactory signatures. Canadian Journal of Zoology 79: 1296-1300.

VAUGHAN TA (1986) Mammalogy. Third edition. Saunders College Publishing, Fort Worth, Texas. 576 pp.

WILSON SC \& DG KLEIMAN (1974) Eliciting play: a comparative study. American Zoologist 14: 341-370.

WISTRAND H (1974) Individual, social, and seasonal behavior of the thirteen-lined ground squirrel (Spermophilus tridecemlineatus). Journal of Mammalogy 55: 329-347.

WOODS CA \& DK BORAKER (1975) Octodon degus. American Society of Mammalogists, Mammalian Species 67: 1-5.

YÁÑEZ JL (1976) Ecoetología de Octodon degus. Bachelor in Sciences Thesis, Universidad de Chile, Santiago, Chile. 67 pp.

ZAR JH (1996) Biostatistical analysis. Third edition. Prentice Hall, Inc., Upper Saddle River, New Jersey. 662 pp. + appendixes. 